\title{
Blackboard as a Motivator for Saudi EFL Students: A Psycholinguistic Study
}

\author{
Jamal Kaid Mohammed Ali ${ }^{1}$ \\ ${ }^{1}$ English Department, College of Arts, University of Bisha, Saudi Arabia \\ Correspondence: Jamal Kaid Mohammed Ali, English Department, College of Arts, University of Bisha, Bisha, \\ Saudi Arabia. Tel: 966-537-504-939. E-mail: jamalalhomaidi@gmail.com
}

Received: April 18, 2017 Accepted: May 8, 2017 Online Published: July 26, 2017

doi:10.5539/ijel.v7n5p144 URL: http://doi.org/10.5539/ijel.v7n5p144

\begin{abstract}
Blackboard is a learning management system that provides students with an opportunity to access the course at their convenience. Blackboard makes it possible for students to do online activities, interact with other students and their teachers, review instructional materials, and listen to the recorded classes. Students can also attend live lectures and discussion via virtual classes (collaborative blackboard) from homes, cafés, or from anywhere they choose. All of these features can be accessed by students anytime and anywhere. This facility might motivate English as a Foreign Language (EFL) students to study effectively and efficiently. The purpose of this research is to investigate the use of Blackboard system in teaching and learning and evaluate its influence on motivating Saudi English students. It looks at the role of Blackboard on English students' motivation from their own point of view and tries to determine whether students encounter issues that affect their motivation. El-Seoud et al. (2014, p. 2) believed that "the success or failure of online instruction is perhaps related to student motivation". This study is conducted at the University of Bisha in Saudi Arabia. The sample consisted of 80 students from the English Department. This is a mixed method study of the students who use Blackboard for online learning. The study found that using Blackboard motivated students to work harder and learn better than traditional methods of learning. It also found that students believe that Blackboard is a motivating factor. Some demotivating factors have also been identified in this study.
\end{abstract}

Keywords: Saudi EFL students, Blackboard, e-learning, LMS, psycholinguistics, motivation, Saudi Arabia

\section{Introduction}

Saudi Arabia is a country that is making progress in the field of electronic learning. It is one of the top countries with regard to rapid advancement and progress in the use of technology. This can be seen by its proliferation in modern Saudi society and particularly in academia. Saudi Arabia has been anticipated to be one of the fastest growing countries over the world in e-Learning area (CITC 2010, cited in Alkhalaf et al., 2012). Learning management systems are now used by majority of Saudi universities to achieve education quality as e-learning facilitates education quality in the universities since the technology can provide interactive and active learning. Lin, Chen, \& Nien (2014) argued that Blackboard can enhance learning interests; learning materials can be re-used over and over, teachers can use multimedia to express the content and meaning of e-learning. Blackboard allows for individual teaching and learning with no space or time limitations. This study investigates whether Blackboard increases or decreases Saudi EFL students' motivation to study English. Therefore, if it increases Saudi EFL students' motivation, the study will suggest building on that increase. And if it decreases motivation, the study will find out how to manage those issues.

\subsection{Blackboard}

Blackboard is an online course management software designed to enhance teaching and learning efforts. The teacher can add teaching materials such as audios, videos, PowerPoint, animation, links, and so forth to Blackboard course shell. The teacher can give students assignments, quizzes, and surveys. S/He can create discussion forums, blogs, wikis, portfolios and groups for student-student and student-teacher interaction. The teacher can also track and assess students. Blackboard has many important features such as SafeAssign, student preview, enhanced cloud profile, collaborate integration, group management, grading enhancements, social learning, Blackboard drive, calendar, content editor, course enrollments, retention centre, dynamic content and active collaboration. 
Even though Blackboard has been used in Saudi Arabia for nearly ten years, there is little research on the role of Blackboard on Saudi EFL students' motivation. Many studies have investigated Blackboard's effect on students' attitudes, perception, problems, opportunities, and so on. They have not studied the impact of Blackboard on motivation. The research has largely ignored the role of motivation in the online learning environment due to the assumption that e-learners are self-motivated and active learners (Nehme, 2010).

\subsection{Motivation}

Motivation has been given different names and characteristics without an agreed-upon definition. It is a complex and multifaceted construct according to Gardner (1985). Dörnyei (2001, cited in Keblawi, 2009, p. 24) stated that researchers disagree about everything that relates to the concept of motivation. He called it "no more than an obsolete umbrella that hosts a wide range of concepts that do not have much in common."

Dörnyei (1998, p. 117) stated that "Researchers seem to agree that motivation is responsible for determining human behaviour by energising it and giving it direction, but the great variety of accounts put forward in the literature of how this happens may surprise even the seasoned researcher." Gardner (1985, p. 10) defined L2 motivation as "the extent to which an individual works or strives to learn the language because of a desire to do so and the satisfaction experienced in this activity". Ryan \& Deci (2000, p. 2) argued that there are two types of motivation: intrinsic and extrinsic. They stated that the most basic distinction is between them is that intrinsic motivation refers to doing something because it is inherently interesting or enjoyable, and extrinsic motivation refers to doing something because it leads to a separable outcome. The present study follows Ryan \& Deci (ibid).

\section{Research Questions}

The present study aims to achieve some objectives that can be summarised in the following research questions:

1) Are Saudi EFL students intrinsically or extrinsically motivated to use Blackboard?

2) Is there a difference between students' motivation in traditional learning and Blackboard learning?

3) What are the issues that motivate or demotivate Saudi EFL students to use Blackboard?

\section{Review of Literature}

Motivation is considered very important in psychology and education. Dörnyei, (1998) argued that high motivation can make up for considerable deficiencies both in one's language aptitude and learning conditions. Zein (2016, p. 1) stated that "Classroom motivation has been the subject of a significant body of research lately; however most EFL classroom problems pertaining to motivation remain largely unchanged, a fact which intensifies the need to further appraise the most appropriate type of motivation in EFL classrooms". Sucaromana $(2013$, p. 3) stated that "the demands of students are more effectively met with the use of technology" Lin, Chen and Nien, (2014) argued that in e-learning, the teacher's role is guidance. Teachers are not in the role of explaining course content. And the students become more active. Therefore, e-learning changes the responsibility of learning from teachers to students. E-learning is participation-based learning, which emphasises the student as prime. Noour \& Hubbard (2015) found that blended learning provides Egyptian students with multiple opportunities for enhancing and motivating their future learning. Today's students are called net generation and digital natives because they "have been immersed in a world infused with networked and digital technologies, they behave differently to previous generations." (Jones \& Shao, 2011, p. 2).

Much has been done to motivate Saudi EFL students to study English. Researchers focused on the lack of motivation, why the students are not motivated, is there a motivation or not, techniques to motivate students, and so on. Motivation has been sought and techniques have been tried in Saudi Arabia with fruitful outcomes. Alshahrani (2016), Alshehri (2009), and Moskovsky et al. (2016) investigated the validity of the motivational self-system in Saudi Arabian EFL context. Mahdi (2015) developed strategies to motivate reluctant students and Al-Zubairy (2012) studied integrative and instrumental motivation. Choudhury (2015) used literature as motivation and Moskovsky \& Alrabai (2009) studied intrinsic motivation.

The Blackboard learning management system has been researched in Saudi Arabia. Researchers focused on attitudes and perceptions (Al Zumor et al., 2013; Ja'ashan, 2015; Alaidarous \& Madini, 2016) and as improving listening and speaking skills (Hussein, 2016).

Two studies were on blended e-learning and motivation Noour \& Hubbard (2015) and Alhazbi (2015). But both were conducted with non EFL students and non-Saudi students. The first one was on Egyptian students of Colleges of International Transport and Logistics (CILT) at the Arab Academy for Science, Technology and Maritime Transport (AAST\&MT) in Egypt by Noour and Hubbard (2015). The second one was on Qatari students of Computer Programming Courses by Alhazbi (2015). Another study was conducted by Sucaromana 
(2013) on the impact of blended learning on the intrinsic motivation of Thai EFL students.

This research paper is different from previous studies as it is on the Saudi Arabian context. It takes into account Blackboard as an e-learning tool and its impact on Saudi EFL students' intrinsic and extrinsic motivation to study English.

\section{Methods}

\subsection{Questionnaire Design}

The questionnaire has been designed with three sections. The first section contains questions on students' background, such as level of studies and which courses have been studied via Blackboard. It also contains questions on how many hours students spend studying via Blackboard or traditional methods. The last question is regarding the workshop training on Blackboard usage. The second part was made up of Likert-Scale items with five responses ranging from Strongly Agree to Strongly Disagree. The questionnaire included 16 items of students' motivation in learning English through Blackboard. Nine of the items deal with intrinsic motivation and seven deal with extrinsic motivation. The third section of the questionnaire is an open-ended section. It was only one item. Students were asked to mention some of the issues that motivate or demotivate them in effectively using Blackboard for learning purposes. It was translated to Arabic language in order to assure that students understand the question and then write helpful responses. In addition to translating the question to Arabic language, the researcher informed the respondents that they can write in English or Arabic which makes them write freely without any language obstacles, particularly those who are in level 1 or 2 . Four experts from applied linguistics and psychology reviewed the questionnaire and provided feedback throughout the initial and final stages of the instrument development process. Suggestions from Blackboard trainers were also incorporated in order to improve the validity of the items.

\subsection{Sampling}

This paper is particularly intended to measure the role of Blackboard on motivation. A convenience sample was selected to conduct the study and achieve its objectives. This sample consisted of 80 male EFL students from English Department, College of Arts, University of Bisha, Saudi Arabia. Table 1 shows the frequencies and percentages for the demographic variables.

Table 1. Frequencies and percentages for the demographic variables $(\mathrm{N}=80)$

\begin{tabular}{lll}
\hline Variables & N & $\%$ \\
\hline Highest education level & & \\
1 to $2\left(1^{\text {st }}\right.$ Year $)$ & 20 & 25.0 \\
3 to $4\left(2^{\text {nd }}\right.$ Year $)$ & 20 & 25.0 \\
5 to $6\left(3^{\text {rd }}\right.$ Year $)$ & 19 & 23.8 \\
7 to 8 ( $4^{\text {th }}$ Year $)$ & 21 & 26.3 \\
Time spent on Blackboard & & \\
Less than one hour & 12 & 15.0 \\
1 to 3 hours & 33 & 41.3 \\
4 to 6 hours & 22 & 27.5 \\
7 or more hours & 13 & 16.3 \\
Time spent on traditional learning & & \\
Less than one hour & 7 & 8.8 \\
1 to 3 hours & 33 & 41.3 \\
4 to 6 hours & 23 & 28.8 \\
7 or more hours & 17 & 21.3 \\
Participated in Blackboard workshop & & \\
Yes & 3 & 3.8 \\
No & 77 & 96.3 \\
\hline
\end{tabular}

The sample consisted of 80 students. It was chosen from level 1 to level 8 . The largest percentage of respondents (26.3\%) had completed between seven to eight levels of education. Close to half $(41.3 \%, n=33)$ spent between one to three hours using Blackboard to learn English while 43.8\% $(n=35)$ spent more than three hours using Blackboard to learn English. Close to half $(41.3 \%, n=33)$ spent between one to three hours using traditional methods to learn English and $50.1 \%(n=40)$ spent more than three hours using traditional methods to learn English. Only 3.8\% $(n=3)$ attended a Blackboard workshop. 


\subsection{Analytical and Statistical Procedures}

Before the data were analyzed, the processes of editing, coding, classification, and tabulation of the data had to be completed. After analyzing the data and presenting the results in tables, the results of the data analyses were interpreted in detail. The consolidation and inferring were declared throughout the discussion. Then the findings were stated out in the conclusion.

\section{Results and Discussion}

\subsection{Predictors of Intrinsic and Extrinsic Motivation}

The first research question sought to determine whether using Blackboard would foster intrinsic and extrinsic motivation in EFL Saudi learners. To answer this research question, two regression procedures were conducted (one for each motivation subscale). The predictors included in both regression models were level of education, time spent using traditional methods, Blackboard workshop attendance, and time spent using Blackboard. Table 2 shows the regression results for the intrinsic and extrinsic motivation models.

Table 2. Regression results for the intrinsic and extrinsic motivation models $(\mathrm{N}=80)$

\begin{tabular}{|c|c|c|c|}
\hline Variables & $B$ & $S E$ & $\beta$ \\
\hline \multicolumn{4}{|l|}{ Intrinsic motivation } \\
\hline Level of education & -.00 & .08 & -.00 \\
\hline Time spent using Blackboard & .13 & .11 & .17 \\
\hline Time spent using traditional methods & -.12 & .11 & -.16 \\
\hline Blackboard workshop $(0=$ no; $1=$ yes $)$ & .68 & .44 & .18 \\
\hline \multicolumn{4}{|l|}{ Overall model $F(4,75)=.94, p=.444, R^{2}=.048$} \\
\hline \multicolumn{4}{|l|}{ Extrinsic motivation } \\
\hline Level of education & .02 & .08 & .04 \\
\hline Time spent using Blackboard & .04 & .11 & .05 \\
\hline Time spent using traditional methods & -.14 & .11 & -.18 \\
\hline Blackboard workshop $(0=$ no; $1=$ yes $)$ & .41 & .45 & .11 \\
\hline Overall model $F(4,75)=.65, p=.631, R^{2}=.03$ & & & \\
\hline
\end{tabular}

\subsubsection{Intrinsic Motivation}

Cronbach's alpha for the intrinsic motivation subscale was .81. According to Per Nunnally \& Bernstein (1994), a measure is reliable if its Cronbach's alpha value is .70 or higher. As such, the intrinsic motivation subscale was reliable. Table 2 shows that intrinsic motivation scores ranged from 1.89 to 5 ; the mean intrinsic motivation score was $3.71(S D=.72)$. The regression results revealed that time spent using Blackboard did not significantly predict intrinsic motivation, $\beta=.17, p=.246$. Time spent using traditional methods also did not significantly predict intrinsic motivation, $\beta=-.16, p=.268$. The other two predictors (level of education and Blackboard workshop attendance) did not significantly predict intrinsic motivation.

\subsubsection{Extrinsic Motivation}

Cronbach's alpha for the original seven-item extrinsic motivation subscale was unacceptable at 45 . Items 13 and 16 had negative item-total correlations and were thus excluded. Alpha increased to an acceptable .75 when these two items were excluded. Thus, this five-item subscale was used in subsequent procedures. Table 2 reveals that extrinsic motivation scores ranged from 1.80 to 5 ; the mean extrinsic motivation score was $3.76(S D=.73)$. The regression results indicated that time spent using Blackboard did not significantly predict extrinsic motivation, $\beta$ $=.05, p=.734$. Time spent using traditional methods also did not significantly predict extrinsic motivation, $\beta=$ $-.18, p=.245$. The other two predictors (level of education and Blackboard workshop attendance) did not significantly predict extrinsic motivation.

\subsection{Predictors of Blackboard and Traditional Methods}

The second research question sought to determine whether motivation would differentially affect time spent using Blackboard and traditional learning methods. To answer this research question, two regression procedures were conducted (one for each type of learning). The predictors included in both regression models were level of education, Blackboard workshop attendance, intrinsic motivation, and extrinsic motivation. Table 3 shows regression results for Blackboard and traditional methods. 
Table 3. Regression results for blackboard and traditional models $(\mathrm{N}=80)$

\begin{tabular}{llll}
\hline Variables & $B$ & $S E$ & $\beta$ \\
\hline Blackboard model & & & \\
Level of education & .23 & .09 & .28 \\
Blackboard workshop $(0=$ no; $1=$ yes $)$ & -.52 & .56 & -.11 \\
Intrinsic motivation & .24 & .19 & .19 \\
Extrinsic motivation & -.22 & .19 & -.17 \\
Overall model $F(4,75)=2.58, p=.044, R^{2}=.121$ & & & \\
Traditional model & & & \\
Level of education & .16 & .09 & .20 \\
Blackboard workshop $(0=$ no; $1=$ yes $)$ & -.01 & .57 & -.00 \\
Intrinsic motivation & .08 & .19 & .06 \\
Extrinsic motivation & -.23 & .19 & -.19 \\
Overall model $F(4,75)=1.25, p=.299, R^{2}=.062$ & & & \\
$.05 .{ }^{* *} p<.01{ }^{* * *} p<.001$. & &
\end{tabular}

Note. ${ }^{*} p<.05 .{ }^{* *} p<.01 .^{* * *} p<.001$.

\subsubsection{Blackboard Time}

The regression results in table 3 indicated that neither intrinsic $(\beta=.19, p=.208)$ nor extrinsic motivation $(\beta=$ $-.17, p=.240)$ significantly predicted time spent learning English using Blackboard. But education level significantly predicted Blackboard time, $\beta=.28, p=.015$. The higher the level of the respondents, the more time they spent using Blackboard to learn English. Blackboard workshop attendance did not significantly predict Blackboard time.

\subsubsection{Time Using Traditional Methods}

The regression results in table 3 revealed that neither intrinsic $(\beta=.06, p=.682)$ nor extrinsic motivation $(\beta=$ $-.19, p=.220$ ) significantly predicted time spent learning English using traditional methods. Education level also did not significantly predict time spent learning English using traditional methods. The other two predictors (level of education and Blackboard workshop attendance) did not significantly predict time using traditional methods.

\subsection{Analysis of Questionnaire Items}

Table 4 shows the total mean score of the questionnaire items. However, items 13 and 16 were excluded from the total mean score because they had negative item-total correlations (see 5.1.2).

Table 4. The mean of the questionnaire items

\begin{tabular}{|c|c|c|}
\hline SN & Items & Mean \\
\hline 1. & Studying English via Blackboard is important because it will make me more knowledgeable person. & 4.05 \\
\hline 2. & Studying English via Blackboard is important because it will help me to get a good job. & 3.6125 \\
\hline 3. & $\begin{array}{l}\text { Studying English via Blackboard important because other people will respect me more if I know } \\
\text { English and Blackboard. }\end{array}$ & 3.75 \\
\hline 4. & Being able to use Blackboard makes me feel superior to others. & 3.725 \\
\hline 5. & $\begin{array}{l}\text { Taking quizzes, exams and assignments on Blackboard motivates me better than taking classroom } \\
\text { ones. }\end{array}$ & 3.9625 \\
\hline 6. & Blackboard inspires me to more active and autonomous learning. & 3.8375 \\
\hline 7. & Studying English courses via Blackboard is fun. & 3.75 \\
\hline 8. & I benefit from my classmates' participations in the Discussion Board. & 3.975 \\
\hline 9. & The Discussion Board of Blackboard helps me share and help others which confirm my abilities. & 3.7375 \\
\hline 10. & I enjoy working with Blackboard tools and materials. & 3.65 \\
\hline 11. & If I had the choice, I would like to attend several workshops on Blackboard. & 3.9875 \\
\hline 12. & If I had the choice, I would like to study all my English courses on supportive blended or E-learning. & 3.75 \\
\hline 13. & I will not choose Blackboard courses if my classmates do not do so. & 2.9625 \\
\hline 14. & Doing Blackboard activities is boring. & 3.0875 \\
\hline 15. & I like to participate in Blackboard even if it is not graded. & 3.2875 \\
\hline 16. & I participate in Blackboard to get grades. & 3.75 \\
\hline \multicolumn{2}{|c|}{ Sum of Means } & 3.726 \\
\hline
\end{tabular}


The findings show that the respondents have a high level of motivation. This is evident by the total mean score of 3.726. The item 1 in the questionnaire, Studying English via Blackboard is important because it will make me more knowledgeable person, has the highest mean score (4.05) which indicates that students have intrinsic motivation to learn English via Blackboard. The item 11 in the questionnaire, If I had the choice, I would like to attend several workshops on Blackboard, has an average mean score (3.99) which indicates that students feel the need for more training on practical aspects of Blackboard. The item 14, Doing Blackboard activities is boring, with an average mean score (3.09) points out that there is considerable need for students' wanting of training in practical aspects. The same was observed from qualitative analysis of the questionnaire where $58.5 \%$ of students stated that if we want them to like Blackboard, we should teach them how to use it. The item 5, Taking quizzes, exams and assignments on Blackboard motivates me better than taking classroom ones, compares between learning language through Blackboard and learning language through traditional classroom methods. The results with an average mean score of 3.96 can be perceived as that students find it more comfortable and convenient learning more through Blackboard than traditional classroom methods. Items 6, Blackboard inspires me to more active and autonomous learning, and item 7, Studying English courses via Blackboard is fun, have the average mean scores (3.84) and (3.75) respectively. The item 15, I like to participate in Blackboard even if it is not graded, has an average mean score (3.75) which shows that students are extrinsically motivated to learn English via Blackboard. Generally speaking, the overall mean score of students' responses shows a high level of intrinsic and extrinsic motivation.

\subsection{Students' Issues}

The third research question sought to gather more evidence on the issues of overall using Blackboard by the students. This was the last part of the questionnaire which is an open-ended in nature. The aim of this part was to obtain a qualitative data. Students were asked to mention some of the issues that motivate or demotivate them in effectively using Blackboard for learning purposes. Students' responses are presented in table 5 below.

Table 5. Students' responses to an open-ended questionnaire

\begin{tabular}{llll}
\hline No & Items & Frequency & Percentage \\
\hline 1 & They requested the administration to get Blackboard Mobile Learn license. & 50 of 80 & $62 \%$ \\
2 & They requested the administration to provide them workshops on using Blackboard. & 47 of 80 & $58.5 \%$ \\
3 & They requested teachers to give them unlimited or multiple attempts. & 42 of 80 & $52.5 \%$ \\
4 & They requested teachers not to give them too many activities. & 40 of 80 & $50 \%$ \\
5 & They requested the administration to provide them Lab in the Department of English & 38 of 80 & $47.5 \%$ \\
& in addition to the main labs. & & 25 of 80 \\
6 & They requested the administration to increase Blackboard marks. & 25 of 80 & $31 \%$ \\
7 & They requested teachers not to restrict the date for submission. & 17 of 80 & $21 \%$ \\
8 & They requested teachers to use Arabic version of Blackboard. & 13 of 80 & $16 \%$ \\
9 & They requested teachers not to complicate Blackboard activities. & 10 of 80 & $12.5 \%$ \\
10 & They requested teachers to give clear instruction (to follow Quality Matters Rubric). \\
11 & They requested the administration to give them iPads /laptops. & 10 of 80 & $12.5 \%$ \\
12 & They preferred not to use Blackboard at all. & 5 of 80 & $6 \%$ \\
\hline
\end{tabular}

From the findings of the open-ended questionnaire, it was observed that the issues given by students fall into two groups. Most of the issues were given only by students from lower levels 1 to 4 (i.e., students studying $1^{\text {st }}$ and $2^{\text {nd }}$ years of under-graduation). It was also observed that the issues given by the students from upper levels 5 to 8 (i.e., students studying $3^{\text {rd }}$ and $4^{\text {th }}$ years of under-graduation) mostly match with those issues given by the lower levels 1 to 4 . The common issues given by the students from lower as well as upper levels are items 1, 2, 4, 5, 6, 7, 9 and 10. These common issues indicate that they strongly feel the need and also expect good deal of help from the teachers as well as the administrators. However, interestingly, a couple of the students from upper level had felt differently and so did not go by the issues given by most of the students. To mention, these students did not ask for items 3,8,11, and 12 (Multiple or unlimited attempts should be given to students; Translation of Blackboard to Arabic; iPad/laptop to students to use e-learning, and not to use Blackboard at all).

\section{Conclusion}

This study examined the relationship between Blackboard, Saudi EFL students and the types of motivation used in the study of the English language. This research has evaluated the data provided by the respondents who use Blackboard as an e-learning system. This study found that Blackboard has fostered Saudi EFL students' motivation towards learning English. This finding is consistent with Sucaromana (2013) who found that Thai 
EFL students have higher intrinsic motivation for learning English. It found that students are intrinsically and extrinsically motivated to learn English via Blackboard. It also found that students find Blackboard more motivating than traditional one. This finding is consistent with Lin et al. (2014). They found that e-learning strategy is superior to the traditional learning method regarding learning motivation. This study also found that students of levels 5, 6, 7, and 8 spend more time in both Blackboard and traditional, but the effect is stronger for Blackboard.

It was also found that students' motivation increases after getting used to technical skills and become technologically fluent. The findings are consistent with Asiri et al. (2012). They found that technology skill and competence also play key roles in the adoption of technology in the field of educational instruction. The qualitative study showed that Blackboard can motivate Saudi EFL students as most of the students believe that Blackboard is fun and motivating tool, but they mentioned some obstacles that hinder/affect their interest in Blackboard. They wrote some demotivating factors in which they stated that they are not very much motivated without solving those issues.

\section{Recommendations}

The researcher suggests that a course on computer literacy/skills and Blackboard techniques should be added to the university syllabus and it should be done in the first year (level one or two). This course must be compulsory because students complain about difficulty and pressure which indicates that they cannot use Blackboard properly. The researcher also suggests that having knowledge of computer skills and Blackboard must be a prerequisite for taking blended courses. The open-ended questionnaire's issues necessitate the English Department staff members to sit together and discuss those issues and see what could be done with regard items $3,4,7,8,9,10$ and 12 . The issues in items $1,2,5,6,11$ and 12 also necessitate the university administrators to find solutions to them which will eventually help students learn effectively. A future study should compare English students and Computer students to see the role of technical skills in motivating students to study via Blackboard.

\section{References}

Al Zumor, A. W. Q., Al Refaai, I. K., Eddin, E. A. B., \& Al-Rahman, F. H. A. (2013). EFL Students' Perceptions of a Blended Learning Environment: Advantages, Limitations and Suggestions for Improvement. English Language Teaching, 6(10), 95-110. http://dx.doi.org/10.5539/elt.v6n10p95

Alaidarous, K., \& Madini, A. A. (2016). Exploring EFL Students' Perception in Blended Learning Environment in Saudi Technical Education Context. International Journal of Educational Investigations, 3(6), 69-81.

Alhazbi, S. (2016). Active Blended Learning to Improve Students' Motivation in Computer Programming Courses: A Case Study. In Advances in Engineering Education in the Middle East and North Africa (pp. 187-204). Berlin: Springer International Publishing. https://doi.org/10.1007/978-3-319-15323-0_8

Alkhalaf, S., Drew, S., AlGhamdi, R., \& Alfarraj, O. (2012). E-learning system on higher education institutions in KSA: attitudes and perceptions of faculty members. Procedia-Social Behavioral Sciences, 47, 1199-1205. https://doi.org/10.1016/j.sbspro.2012.06.800

Alshahrani, A. A. S. (2016). L2 Motivational Self System Among Arab EFL Learners: Saudi Prespective. International Journal of Applied Linguistics and English Literature, 5(5), 145-152. http://dx.doi.org/10.7575/aiac.ijalel.v.5n.5p.145

Al-shehri, A. (2009). Motivation and vision: The relation between the ideal L2 self, imagination and visual style. In Z. Dörnyei, \& E. Ushioda (Eds.), Motivation, Language Identity and the L2 Self (pp. 164-171). Clevedon: Multilingual Matters.

Al-Zubeiry, H. (2012). The Socio-psychological Orientations of Saudi Learners of English as a Foreign Language. Umm Al-Qura University Journal \& of languages \& literature, 8, 11-52.

Asiri, M. S., Mahmud, R., Abu-Bakar, K., \& Ayub, A. F. (2012). Factors influencing the use of learning management system in Saudi Arabian Higher Education: A theoretical framework. Higher Education Studies, 2(2), 125-137. http://dx.doi.org/10.5539/hes.v2n2p125

Choudhury, M. A. (2015). Texts, Contexts and Motivational Strategies in Teaching Literature to Saudi Students. International Journal of English Language Teaching, 3(8), 19-35.

Dörnyei, Z. (1998). Motivation in second and foreign language learning. Language Teaching, 31(03), 117-135. https://doi.org/10.1017/S026144480001315X 
El-Seoud, S. A., Taj-Eddin, I. A., Seddiek, N., El-Khouly, M. M., \& Nosseir, A. (2014). E-Learning and Students' Motivation: A Research Study on the Effect of E-Learning on Higher Education. International Journal of Emerging Technologies in Learning, 9(4), 689-695. http://dx.doi.org/10.3991/ijet.v9i4.3465

Gardner, R. C. (1985). Social psychology and second language learning: The role of attitude and motivation. London, England: Edward Arnold.

Hussein, E. (2016). The Effectiveness of Using Blackboard in Improving the English Listening and Speaking Skills of the Female Students at the University of Hail. Advances in Social Sciences Research Journal, 3(12), 81-93. https://doi.org/10.14738/assrj.312.2379

Ja'ashan, M. M. N. H. (2015). Perceptions and Attitudes towards Blended Learning for English Courses: A Case Study of Students at University of Bisha. English Language Teaching, 8(9), 40-50. http://dx.doi.org/10.5539/elt.v8n9p40

Jones, C, \& Shao, B., (2011). The net generation and digital natives: implications for higher education. York: Higher Education Academy.

Keblawi, F. (2009). A review of language learning motivation theories. JAMEEA, (12), 23-57.

Lin, H. M., Chen, W. J., \&Nien, S. F. (2014). The Study of Achievement and Motivation by e-Learning-A Case Study. International Journal of Information and Education Technology, 4(5), 421-425. https://doi.org/10.7763/IJIET.2014.V4.442

Mahdi, D. A. (2015). Motivating Reluctant EFL Students to Talk in Class: Strategies and Tactics. Theory and Practice in Language Studies, 5(8), 1703-1709. http://dx.doi.org/10.17507/tpls.0508.22

Moskovsky, C., \&Alrabai, F. (2009). Intrinsic motivation in Saudi Learners of English as a foreign language. The Open Applied Linguistics Journal, 2(1), 1-10. https://doi.org/10.2174/1874913500902010001

Moskovsky, C., Assulaimani, T., Racheva, S., \& Harkins, J. (2016). The L2 motivational self system and L2 achievement: A study of Saudi EFL learners. The Modern Language Journal, 100(3), 641-654. https://doi.org/10.1111/modl.12340

Nehme, M. (2010). E-learning and students' motivation. Legal Education Review, 20, 223-239.

Noour M. A. T., \& Hubbard, N. (2015). Self-Determination Theory: Opportunities and Challenges for Blended e-Learning in Motivating Egyptian Learners. Procedia-Social and Behavioral Sciences, 182, 513-521. https://doi.org/10.1016/j.sbspro.2015.04.836

Nunnally, J. C., \& Bernstein, I. H. (1994). Psychometric theory. New York: McGraw-Hill.

Ryan, R. M., \& Deci, E. L. (2000). Intrinsic and extrinsic motivations: Classic definitions and new directions. Contemporary Educational Psychology, 25(1), 54-67. https://doi.org/10.1006/ceps.1999.1020

Sucaromana, U. (2013). The Effects of Blended Learning on the Intrinsic Motivation of Thai EFL Students. English Language Teaching, 6(5), 141-147. http://dx.doi.org/10.5539/elt.v6n5p141

Zein, F. A. (2016). The Pedagogical Implications of EFL Learner Motivation in Sattam Bin Abdulaziz University. International Journal of Language Learning and Applied Linguistics World, 11(2), 116-134.

\section{Copyrights}

Copyright for this article is retained by the author(s), with first publication rights granted to the journal.

This is an open-access article distributed under the terms and conditions of the Creative Commons Attribution license (http://creativecommons.org/licenses/by/4.0/). 